\title{
TANITMA: Ahmet Koçak, Gece ve Deniz Şairi Tahsin Nahit Üzerine, Akıl Fikir Yayınları, İstanbul 2016
}

Tuba YILMAZ1

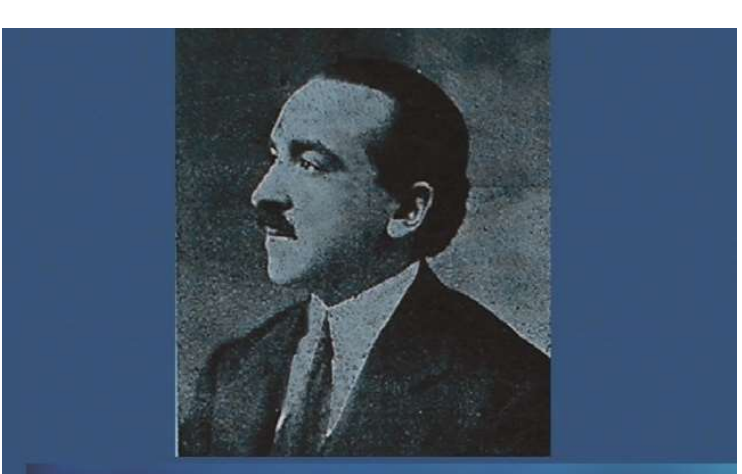

Ahmet KOÇAK

Gece ve Deniz Şairi TAHSIN NAHIT

Edebiyat tarihçiliği, Yeni Türk Edebiyatının problemli alanlarından birisidir. $\mathrm{Bu}$ sahadaki boşlukları doldurmanın yollarından biri, edebî tarihimiz içinde karanlıkta kalan isimlerin eserleriyle birlikte tam bir dökümünün gerçekleştirilmesiyle mümkündür. Böylece alana yeni katkılar sunan eserler, aynı zamanda edebiyat tarihi içerisinde sağllğında tanınan, ancak ölümüyle birlikte tarihe karışan isimlerin yeniden keşfedilmesine, aydınlatılmasına vesile olacaktır. Genelde edebiyat tarihçiliğinin, özelde ise Yeni Türk Edebiyatının bütün yönleriyle vuzuha kavuşması edebî şahsiyetleriyle beraber, eserlerinin de ortaya çıkartılmasıyla mümkün olacaktır.

Bu bağlamda, daha önce Şehbenderzâde Filibeli Ahmet Hilmi'nin Hikmet Yazılarl (2005), sonrasında 1872-190o yıllarında kaleme alınan romanlardan yola çıarak oluşturulan Türk Romanında Avrupa (2013) ve Ahmet Mithat Efendi'nin damadı olan Yenişehirlizâde Halit Eyüp'ün Kayıkla Bir Cevelan (2016)'ı gibi kıymetli çalışmalara imza atan Ahmet Koçak, son olarak Fecr-i Âti edebiyat topluluğununum teşekkülünde mühim bir fonksiyonu olan, yaşadığı dönemin edebiyat mahfillerinde önde gelen isimlerinden birisi olan, ancak daha sonraki yllarda geri planda kalan Tahsin Nahit (ö.1919) üzerine yaptı̆̆ı Gece ve Deniz Şairi Tahsin Nahit (2016) isimli çalışmayı, bu ismin tekrar hatırlanmasıyla beraber edebiyat araştırmacılarının istifadesine sunar. Yazarın yaptığı bu çalışmayı, Tahsin Nahit üzerine yaptığı Tahsin Nahit’in Bütün Şïrleri (2016) adlı çalışmasıyla birlikte düşünmek ya da o çalışmanın devamı olarak değerlendirmek gerekir.

Tahsin Nahit, II. Meşrutiyet sonrası, dönemin önde gelen yirmiye yakın dergi ve gazetelerinde şiirleri yayımlanan ve özellikle bu dönemde Türk tiyatrosunun gelişip kök salmaya başlamasında telif ve adapte tiyatrolarılya alanın önemli isimleri arasında yer alır. Tahsin Nahit’in bu yönünü değerlendiren çalışmalar da yapılmıștır. Tahsin Nahid’in Piyesleri (2005)² çalıșması bunlardan biridir. Fakat, Ahmet Koçak'ın bu çalışmasını diğerlerinden farklı kılan şairin "biyografisiyle beraber, Fecr-i Âti içerisindeki konumu, şiirleri ve düz yazıları üzerine bir incelemeyi amaç edinmiş” olmasıdır (s.6).

Beş bölümden oluşan kitabın ilk bölümü; “Tahsin Nahit’in Hayatı ve Eserleri” (s.21-63) başlığını taşır. Bu bölümde, şairin kronolojik hayat hikâyesinin ötesinde doğum tarihinden ölümüne kadar şair

\footnotetext{
1 İstanbul Medeniyet Üniversitesi, Sosyal Bilimler Enstitüsü, Türk Dili ve Edebiyatı ABD Doktora Öğrencisi, tuba.yilmazz@hotmail.com [Tanıtma yazısı kayıt tarihi: 27.7.2017-kabul tarihi: 10.10.2017]; DOI: 10.2900o/rumelide.347569

$2 \quad$ Tahsin Nahid’in Piyesleri, Hzl.: Ayfer Yılmaz, Kazım Çandır, Ürün Yayınları, Ankara 2005.
} 
hakkında muhtelif iddialara, çeşitli yazılara ve kaynaklara, derinlemesine bilgilere yer verilir. Genç yaşta babasını kaybeden şairin çocukluğundan itibaren ruhunda açılan derin yaralara dair Ahmet Haşim'in kaleminden çıkan cümlelerle tanıklık edilmesi dikkat çekerken, kızı Prof. Dr. Mina Urgan'ın babasının aldığı iyi eğitim, özellikle Fransızcası, hakkında hatıralarından yola çıkarak; "Babam yönetim kurulu üyesi olduğu Darülbedayi, yani Şehir Tiyatroları'na gelmesi için Antonie ile yazışmış. Birkaç mektubunun müsveddelerini okuyunca şaşırdım kaldım. Çünkü ancak iyi eğitim görmüş bir Fransız böyle bir ustalıkla kullanabilir o dili” (s.22) şeklinde kullandığı ifadeler, yukarıda sözünü ettiğimiz gibi eserde, Tahsin Nahit'in hayatına dokunan isimlerin görüşleriyle biyografisinin ortaya konulduğuna örneklerdendir.

Yine bu bölümde şairin ölümünün ardından Büyük Мecmua, Şair Nedim, Yarm gibi dergilerde Süleyman Nazif, Mehmet Rauf, Mithat Cemal, Refik Halit, Faruk Nafiz gibi önemli isimlerin kaleme aldıkları yazılara yer verilir.

Kitabın ikinci bölümünü “Fecr-i Âti”ye (s.64-94) ayıran yazar, bu döneme, topluluğun ortaya çııışı, Encümen-i Edebisi Beyannamesi, topluluğun dağılışı ve Tahsin Nahit’in topluluktaki yerine kadar geniş bir yelpazeden bakar. Böylece okuyucu, Fecr-i Âti topluluğunu hatırlayarak Tahsin Nahit'in bu topluluktaki konumuna dair bilgi edinmiş olur.

İlk bölümde şairin hayatının yanı sıra eserlerinden de bahseden Koçak, bu ilk bölümde Tahsin Nahit'in şiirleri, tiyatroları, tiyatro eleştirileri, adapteleri, Batı edebiyatı, sanat ve edebiyata dair yazıları hakkında bilgiler verir.

Üçüncü bölüm "Tahsin Nahit’in Şiirleri” (s.95-129), dördüncü bölüm "Şiirlerinin Yapı ve Şekil Bakımından İncelenmesi” (s.130-144) ve son bölüm ise "Dil ve Üslup" (s.145-166) olmak üzere şairin şiirlerinin tüm yönleriyle incelendiği müstakil bölümlerden oluşur. Tüm bu bölümlerde incelenen şiirler arasinda;

"Ey hasta kamer, ey ebedi çehre-i meshûr,/ Ey her gece âlâmımı tenvire çlka nûr" (s.103) gibi mısralar, okuyucuya Ahmet Haşim’in "ey" nidalarıyla kamere seslendiği şiirlerini hatırlama zevki sunar. Haşim ile şair arasındaki yakınlık sadece okuyucunun şairin şiirlerden yola çıkarak kurduğu bağın ötesinde olduğu kitapta yer alan bilgiler arasındadır. Tahsin Nahit’i en çok etkileyen isim Ahmet Haşim'dir. Bu durum şüphesiz bir yönüyle Haşim’in iyi şairliğinden kaynaklanır. Fakat iki şair arasındaki kavi bağ, belki de her ikisinin özel hayatlarındaki kayıpların açtığı derin yaraların ortaklığından ileri gelir. Şair de Haşim gibi akşama sığınır ve ilhamını ondan alır. Halit Fahri Ozansoy’un

\section{"Gelse Tahsin Nahit ki Adada her sahili}

Bir Rûh-ı Bî- Kayd ile dolaşmıştı kaç mevsim;

\section{Gelse başı ateșli sembollerle haleli}

'O Belde’nin tunç yüzlü yolcusu Ahmet Haşim” (s. 97) mısraları iki ismin şiir anlayışlarındaki ortaklığı vurgulamak açısından dikkat çeker.

Tahsin Nahit'in şiirleri arasında Akşam/Gece en çok yer kaplayan başlıklardandır. Tabiat ile baş başa kalınan, yarı karanlık, eşyanın sis perdesinde gizlendiği, ilhamın harekete geçmek için elverişli bir ortam olarak kabul edilen akşam saatleri, topluluğun diğer şairleri gibi Tahsin Nahit’in de tercih ettiği vakittir. 

130)

Dolayısıyla akşam, gece, kamer, mehtap, deniz gibi başlıklar Ahmet Haşim gibi onun da şiirini besleyen unsurlardır.

Servet-i Fünun, Şair, Resimli Kitap, Kanad, Fağfur, Mehâsin, Kadın, Jale, gibi içinde kadın dergilerinin de yer aldığı mecmualarda şiirler yayımlayan şairin, bu şiirlerin dışında kendi el yazısıyla kaleme aldığı defterindeki eserlerin ilk kez bu kitapta yer alması bu çalışmayı ayrıca ehemmiyetli kılar. Dolayısıyla bu çalışma, Tahsin Nahit'in daha önce yayımlanmış ya da yayımlanamayan tüm çalışmalarının bir araya getirilmiş olmasıyla önem arz eder. Nitekim "Ekler" kısmı da bu açıdan kitabın dikkat çeken bölümlerinden biridir.

Tahsin Nahit’in vefatıyla ilgili Büyük Mecmua'da yer alan fotoğrafları ve yazıları okuyucuyla paylaşan yazar, bu metinleri günümüz Türkçesiyle de kaleme alarak ilgililerin istifade etmesini sağlar. Ekler kısmında, yukarıda zikrettiğimiz pek çok şair ve yazarın Tahsin Nahit hakkındaki düşüncelerine dönemin mecmualarında yer alan şekli ve Türkçesi ile ulaşma imkânı sunulmuştur. Yine bu ekler arasında, şiirlerinden ve edebî yazılarından örnekler aynı şekilde hazırlanmıştır.

Bu eser, Türk Edebiyatında ilk defa bir sanat ve edebiyat anlayışlarını bir bildiri yayımlayarak ortaya koyan Fecr-i Âti edebiyat topluluğuna mensup Tahsin Nahit’in tekrar hatırlanmasına vesile olduğu gibi, bu alanda yapılacak başka çalışmalara katkıda bulunabilecek niteliktedir. Fecr-i Âti topluluğunun kuruluş aşamasında önemli bir yere sahip olan şair, adalardaki, Cağaloğlu'ndaki ve Haydarpaşa'daki evinin kapılarını, bu topluluğa mensup kişilerin bir araya gelmesi için açar. Nitekim, Cağaloğlu'ndaki bu ev, "kış aylarında gençlerin okul çıkışlarında yahut okuldan kaçtıklarında toplandıkları yer burası olmuştur. Tahsin Nahit’in bu yıllarda yazdığı ve yaz-kış şeklinde uzun iki bölümden oluşan şiirlerinde konunun iç yüzünü, en bakir hislerinin burada olduğunu ifade eder" (s. 91). Burada, adada ve Moda'daki evde Yahya Kemal, Sadrettin Celal, Fazıl Ahmet, Celal Sahir, Yakup Kadri gibi birçok isim ağırlanır.

Bu bağlamda, bir döneme uzaktan tanıklık etmenin yanı sıra bizatihi içinde bulunan, evini edebî bir topluluğun teşekkülü için mekân haline getiren Tahsin Nahit, edebî yönü dışında farklı açlardan değerlendirilebilecek isimler arasında yer alır.

$\mathrm{Bu}$ çalışma, okuyucuların ve araştırmacıların dönemin farklı mecmualarında yayımlanan pek çok eserle ve çok geniş bir yazar/şair kitlesiyle karşlaşmasını sağlar. İngiliz Edebiyat tarihçisi Prof. Dr. Mina Urgan'ın da babası olan Tahsin Nahit üzerine yapılan bu eser, aynı zamanda, sadece şiir ile ilgilenenlerin değil, tiyatro ve Batı edebiyatına gibi alanlara ilgi duyan ve Fecr-i Âti dönemini incelemek isteyenlerin istifade edebileceği önemli kaynaklar arasında yer alır. 